\title{
Multicriteria Decision Analysis and Participatory Decision Support Systems in Forest Management
}

\author{
Montserrat Acosta ${ }^{1}$ and Serafín Corral ${ }^{2, *}$ \\ 1 Department of Techniques and Projects in Engineering and Architecture, University of La Laguna, \\ 38200 Canary Islands, Spain; mmacosta@ull.edu.es \\ 2 CEDESOG-Department of Applied Economics and Qualitative Methods, University of La Laguna, \\ 38200 Canary Islands, Spain \\ * Correspondence: scorral@ull.edu.es; Tel.: +34-9223-17009; Fax: +34-9223-17855
}

Academic Editors: Jan Kašpar, Pete Bettinger, Harald Vacik, Róbert Marušák and Jordi Garcia-Gonzalo Received: 17 February 2017; Accepted: 5 April 2017; Published: 10 April 2017

\begin{abstract}
Growing concern about issues such as environmental quality or the sustainability of natural resources has led to the use of the Decision Support System (DSS), which originated in the business field, and is now part of environmental decision-making processes. The presence of environmental, social, or economic dimensions has helped decision support systems to evolve to be able to tackle investigations that can contemplate all these variables, such as in the case of multicriteria decision analyses. In addition, new lifestyles, in which society recognizes more and more the contribution of forests to its welfare, have led to the need to involve stakeholders in decision-making processes. This article presents a review of different Multicriteria Decision Analysis (MCDA) and participatory decision support systems applied to forest environments. This last point is presented from the perspective of stakeholder participation in the processes and from the point of view of procedures or tools used. To do this, some of the research performed in forest environments within this current century is reviewed.
\end{abstract}

Keywords: DSS; MCDA; forest management; stakeholders' participation; integrated assessment

\section{Introduction}

Decision Support Systems (DSSs) are means or tools to aid decision making. Sprague Jr. [1] argued that DSSs were "characterized as interactive computer based systems, which help decision makers use data and models to solve unstructured problems" [1] (p. 1). However, this definition of DSSs was complemented by considering them as "any system that makes some contribution to decision making" [1] (p. 2). The purpose of a DSS has been to help people to improve decision making, as indicated by Kangas et al. [2]. DSSs were developed in the beginning to support business managers. Later, they generated interest in the management of environmental quality and are considered fundamental for the sustainable management of terrestrial and marine ecosystems [3].

Maintaining these environments is paramount for global environmental well-being, for climate change, species conservation, and biodiversity conservation [4]. Natural resource management presents diverse aspects, such as economic and recreational issues, that have to be considered by decision makers. Mysiak et al. [5] added that "... issues such as the increasing severity of environmental problems and growing conflicts in the exploitation of natural resources have added new challenges to DSS development" (p. 204). Kangas et al. [6] argued "in addition, there is more and more often need to take account of multiple decision makers or participants in natural resource decision making" (pp. 215-216).

The diversity of dimensions (environmental, social, and economic) has determined the search and modelling of systems to process such a variety of information. DSSs have been adapted through 
integrated methodologies and tools-such as Multicriteria Decision Analysis (MCDA) methods-thus facilitating the work of decision makers. Eom [7] expressed that the nature of the DSS tools had evolved considerably and "are equipped with a variety of tools such as graphics, visual interactive modeling, artificial intelligence techniques, fuzzy sets, and genetic algorithms". Thus, for example, as indicated by Kangas et al. [6] in order to respond to the heterogeneity of the data, a range of decision support methods and multi-criteria techniques should be applied.

In the field of natural resources, and more specifically in a forest environment, DSSs have been used in several studies, such as in Ananda [8], related to forest land use policies; Prell, Hubacek, and Reed [9], in the use of national parks; Nordström et al. [10], in urban forest planning; Rosenberger, Needham, Morzillo, and Moehrke [11], in their analysis in the implementation of an access payment system to forests; or Acosta and Corral [12], in the planning of the use of forest tracks.

An important feature of participatory DSS is that it requires the participation of social actors involved in an issue as a way to increase decision-makers' knowledge. This has been one of the determining factors in processes of participatory forest planning, as Vainikainen et al. [13] indicate.

Some authors have previously carried out reviews on forest issues, such as J. Kangas and Kangas [14], or Díaz-Balteiro and Romero [15] on some of the multi-criteria approaches applied to forest issues, or the one carried out by A. Kangas et al. [16] on voting techniques applied to forest planning. In our case, the objective is to review the evolution of participatory DSS and MCDA, focusing on those applied to forestry issues.

Some authors, such as, for example, Ananda et al. [17], de Steiguer et al. [18], Diaz-Balteiro et al. [15], Kangas et al. [14], Mendoza et al. [19], Romero [20], and Sheppard [21], have previously conducted reviews on the use of multicriteria approaches in forest planning. There has been an evolution in the DSSs applied, from more technocratic positions to a growing commitment to the application of more inclusive methodologies and evaluation processes in the face of a growing acceptance of the need to involve social actors in decision-making processes [22]. In this sense, during this review, special attention will be given to the more inclusive MCDAs developed in the last few decades, in order to make a new contribution to the existing literature in this field.

Research has been selected which has provided data, not only on the parameters to be analysed, such as alternatives and criteria, but also in regards to how it was chosen. The articles have been selected taking into account their relevance based on the number of citations received and the scientific character of the publications in which they have been published.

In fact, this review is based on an exhaustive survey of a large number of journal articles and chapters published on participatory multi-criteria analysis applied to environmental problems and forest issues in particular, in the last two decades.

This review uses as primary sources those articles published in scientific journals related to forestry, environmental management and planning, DSSs and participatory approaches, and life and social sciences publications. Together, chapters and books with citations were reviewed. The number of citations as well as the review process to which the papers were subjected was taken into account in the selection process.

Thus, the material subjected to analysis was reviewed as follows. In a first phase, journals were browsed using the following keywords: forest planning and management, participatory MCA, MCDA, participatory approaches, among others. The searching process was carried out through Google Scholar, Scopus, and Scimago search engines.

In a second step, other scientific papers and books were selected for revision based on the relevance given in the works read during the initial round. In total, 213 papers were revised.

This review focused on the implementation of several MCA approaches and participatory techniques, allowing for a comparison, based on the degree of participation of social actors, in the way that alternatives and criteria were selected and the MCDA method applied. It provides valuable information for experts to choose methods for a given forest planning and management issue. 
To do this, some of the forest research published within this century is reviewed, identifying MCDA in which a technocratic character has been present, in comparison to others that have been more participative. This review describes guidelines that are fundamental to the achievement of the objectives in decision making, which are not only relevant for consideration in forest environments, but also applicable to other environments, where environmental, social, and economic dimensions come into play.

\section{Decision Support Systems}

DSSs emerged in the 1960s and 1970s. Kilgour and Eden [23] express that in those decades, there was a rapid evolution of information systems. Although different terminologies were used to label different DSSs, they were all created with the same purpose, which is to facilitate decision making for managers. Thus, in the 1970s, there was talk of Management Decision Systems (MDS); these systems facilitated the work of managers, so that they could cope with problems through greater knowledge of the environment [24]. In this sense, when it was not possible to structure a decision-making problem, they provided "... models of the environment from which a manager can develop insights into the relationship of his decisions to the goals he wishes to achieve" [24] (p. 28).

A decade later, Scott Morton [25] contemplated Management Support Systems (MSS) and defined them as the use of information technologies as an aid to management. In his research on the "state of the art of research in management systems," he considered three categories within MSS: (1) Data Support; (2) Decision Support; and (3) Executive Support Systems (ESS). In the case of Data Support, it was intended to provide information without regard to its use or to the user. Decision Support System, considered as a subset of MSS, is "... one that is focused on a specific decision or a specific class of decisions" (p. 6). ESS focused on a manager's or group of managers' information needs across a range of relevant areas of concern" (p. 9). In the research developed by Scott Morton [25], 91.9\% of the cases analysed were within the Decision Support category.

It could be said that this last fact was already an indicator of the strong position that DSSs were in two decades from the end of the last century. However, DSSs have had to adapt to changes, for example, the need to consider different dimensions (environmental, social, and economic) has required tools that can process them, such as multi-criteria approaches used in forestry such as in Ananda [8] or Nordström et al. [10], or in the field of water resources, in Paneque Salgado et al. [26]. In addition, the participation of society in decision making has motivated the development of approaches that allow this, such as the surveys used by Rosenberger et al. [11] or Gül et al. [27] in their forestry research, or the focus groups developed by Corral Quintana [28] in public policy-making processes, Corral-Quintana et al. [29] in desertification issues, or Acosta and Corral [12] in forest areas.

All this leads us to consider the existence of two elements: on the one hand, the processes, which may be more or less participatory, and on the other hand, linked to these are the tools used for the development of these processes.

In this paper, we consider that DSSs can be structured into three large modules (see Figure 1) that contemplate the activities. In the first module is the collection of data related to the issue under study. This information can be of a qualitative or quantitative nature. All these data are ordered in the central module of the structure, in which the tools used to process and assess them are located, and may be considered as a single criterion or according to a wider vision with various criteria. In the latter case, the use of multi-criteria assessments could be used. Once the results of the assessments are obtained, they go to the third module where they can be presented through different channels. For example, the presentation of results is sometimes performed through maps processed with Geographic Information Systems (GISs) or graphics such as rankings or dendrograms obtained in the NAIADE (Novel Approach to Imprecise Assessment and Decision Environments) approach, designed by Munda in 1995 and developed by the Joint Research Center of Ispra (Italy) [30]. 


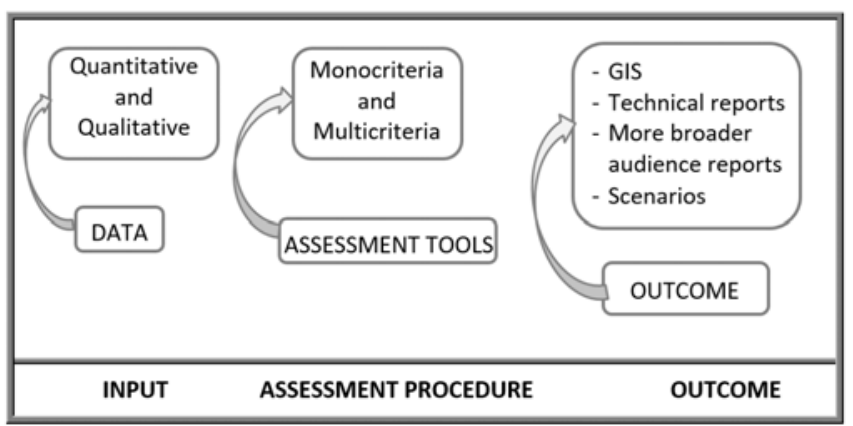

Figure 1. Structure of Decision Support Systems.

GISs "are computer assisted systems for the capture, storage, retrieval, analysis and display of spatial data" [31]. It should be noted that the combination of GIS with multi-criteria reduces the complexity for users in relation to other conventional practices, as indicated Greene et al. [32].

As examples of cases where research studies have presented results with GIS, the case of Greene et al. [32] on forest-dominated landscapes or the research into the effects of the strategies by Fürst et al. [33] might be mentioned. A more detailed analysis on the representation of results in MCDA can be reviewed in Acosta and Corral [12].

Results can also be disseminated through technical reports such as the study carried out by Ramani et al. [34], whose objective was to develop a performance-measurement-based approach to evaluate sustainable transportation for the Texas Department of Transportation. However, with this manner of dissemination of results, a wide diffusion is not obtained. This is the reason why a broader audience report is sometimes used, as in the research project VALSE (VALuation for Sustainable Environments), presented by $\mathrm{O}^{\prime}$ Connor [35]. This project was developed for the assessment and demonstration of policy-making procedures. Procedures were designed and implemented in a manner through which it was possible to address conflicts that arose in four real decision-making scenarios related to natural resources and the environment. One of the phases of the VALSE project included the presentation of the results report to policymakers, researchers, and the interested public, through workshops, symposia, and a set of supporting written documents.

In the following section, some of assessment tools usually applied in forestry MCDA are analysed.

\section{MCDA in Forest Environments According to Different Assessment Tools Used}

DSSs carried out in forest environments have used a variety of procedures or tools that have not only served to increase the initial knowledge about the subjects being investigated, but also, through them, all the information has been processed and assessed. Kangas et al. [2] have recently stated that in planning and decision-making processes, different types of approaches can be applied, since there is no "universal truth" about how to carry out a decision-making process. In this sense, at the end of the last century, Keeney [36] considered it essential to find methods that could reduce the differences that arose between some experts in establishing the consequences derived from carrying out certain alternatives. These differences are also present due to the existence of several decision makers or other stakeholders who have different opinions regarding the problem to be addressed [2].

One of the approaches that allows the treatment of differences among social actors and is also frequently used in forestry planning is the MCDA, defined by Belton and Stewart [37] as a set of approaches that considers several criteria to help explore important decisions, such as corporate decisions or situations where there are many parties involved. Mendoza and Martins [19] added that MCDA allows the treatment of mixed data, both quantitative and qualitative, as well as the opinions of experts. In this sense, as indicated by Kilgour and Eden [23], when the problem to be treated is well defined these approaches can be used. 
There are several examples of the application of multi-criteria methodologies, including forest research, such as the one carried out in the Eastern Alps, Italy by Fontana et al. [38], to compare alternatives for land use. In this analysis, through the PROMETHEE II method they obtained a classification of the alternatives. These authors comment on the flexibility of the method, as it allows them to make modifications to the weightings. Another example of research that has used multi-criteria has been the one by Nordström et al. [10]. In this case, the Analytic Hierarchy Process (AHP) was used for planning the Lycksele urban forest in Sweden. It allowed interested parties to make comparisons of pairs of alternatives related to the specific criteria of the social group to which they belonged. In addition, through AHP it was possible to determine the strength of preference for one criterion or alternative over another. In the research by Ananda [8], AHP was also used-an issue that was evidenced in the Diaz-Balteiro and Romero [15] review. On the other hand, in the case of NAIADE, although its use has not been frequent, this discrete multi-criteria method allows the incorporation of deterministic, stochastic, or diffuse measures of the behaviour of an alternative in relation to a criterion [39].

The conflicts that arise between the desire to consume natural resources and the preservation of forests make it necessary to use "... management strategies that preserve the health and ecological integrity of the forest at the landscape ..." [40] (p. 19). In this sense, Ananda et al. [41] (p. 13) argue that AHP is suitable for forest planning, as it can accommodate conflictual, multidimensional, incommensurable, and incomparable sets of objectives, and furthermore, "... can formalise public participation in decision making and increase the transparency and credibility of the process". Thus, Ananda et al. [41] consider that AHP can be used to obtain compromise solutions, becoming a valid tool for participatory decision making in forest planning. AHP has also been used in reforestation cases for riverbank stabilization and habitat protection, such as in Johnstone River catchment in North Queensland [42], or in combination with a consultation model called DSD V1.1 (Decision Support Dobrova), for the evaluation of the main objectives of forest management in southern Austria [43], or to implement a method proposed by Diaz-Balteiro et al. [44], based on goal programming with Zero-one variables, allowing the overall sustainability of each forest system to be determined.

Qureshi et al. [42] consider that AHP, however, presents some limitations such as: "Questionnaire development can be difficult and time consuming", "Stakeholder interviews can be long and demanding of the interviewer and interviewee", "Results are not always widely accepted" or "Unrealistic expectations about policy decisions can be generated". On the other hand, as stated by Kurttila et al. [45], it can be used to avoid some limitations that are encountered when applying SWOT analysis. For example, the AHP analysis, unlike SWOT, is capable of supporting decision-making processes where uncertainties are present [45].

On the other hand, in the 1960s and 1970s, it was common to use the linear programming (LP) technique [46]. However, when solving multi-objective problems, it was necessary for all immeasurable objectives to be transformed into a common unit of measure, an issue that was often difficult to achieve [46]. Fischer et al. [47] considered that decision makers' preferences tended to present a multi-objective nature in the majority of land resources related issues, so the use of multi-objective optimization approaches would make it possible to cope with those situations in which objectives cannot be expressed in the same measurement unit.

Steuer et al. [48] stated that the use of interactive multiple-objective linear programming simplified decision-making processes, since it was characterized by not having to perform weights. At the same time, the authors pointed out that another of its advantages was that it showed as a solution several results, which would allow the planner to choose the option that he considered the most appropriate. Several aspects, such as not having to perform weights or that it is only the planner or decision maker who select one of the solutions, simplify the process development time, and can be considered an advantage. However, the lack of inclusion of the social actors may result in the possibility that not all of the possible decision alternatives are contemplated, due to the fact that the contributions of all those involved have not been considered. 
The participation of social actors in decision making requires techniques that adapt to new needs [21]. Thus, Sheppard et al. [21] applied a method called public MCA, which focused on the assessment of forest sustainability and allowed for the combination of expert evaluations and stakeholder criteria weighting. In this method, the criteria can be established through the consultation process either by experts or by stakeholders [49]. Consultation processes may be time and budget consuming, which sometimes are limiting factors in research. However, it is a topic to consider, since the inclusion of social actors might facilitate decision-making processes. Thus, Sheppard et al. [21] asked participants about the effectiveness of this public planning process, and the majority (86\%) agreed on the success of MCA as a tool to support decision-making in forest management.

On the other hand, there are tools that allow planners to organize information in a graphical way [50] and, in addition, make it easier for social actors to understand the results of the assessments carried out. For example, Geographic Information Systems (GIS) make it possible to determine and document the geographic location of the opinions of social actors, allowing the generation of thematic maps from data that are stored in numerical layers that facilitate the identification of the location and affected area [51]. In a review by Diaz-Balteiro and Romero [15], they point out that Hytönen et al. [51] proposed a method to incorporate qualitative information provided by several individuals into a geographic information system. This research is also mentioned in the review by A. Kangas et al. [16], in which they emphasize that Hytönen et al. [51] "presented the so-called hope-map method, which can be considered as an application of spatial voting".

GIS has been used in other studies, such as the one by Greene et al. [32] in western Newfoundland, Canada. The objective was to test the MCDA approach based on a GIS, combining the exploratory phase with an assessment phase in an integrated Spatial Decision-Support System (SDSS). These authors consider that the analysis of problems through maps and graphs facilitates the discussion on the subject under study among social actors. Another example of the application of GIS is the research carried out by Hayati et al. [52] in the Baharbon district of Kheyroud forest, in Northern Iran, where the criteria information was transferred to ArcGIS in order to generate map layers. From this information, alternatives for a road network could be designed.

In addition, it is possible to use integrated analyses in which the application of several tools is combined. As an example, Acosta and Corral [12] can be cited, since in their research on the planning of forest track uses, they combine institutional analysis (IA), participatory techniques (PT), and multi-criteria assessment methods. Also, Nordström et al. [10] are supporters of this research system; specifically, they talk about integrating MCDA in participatory forest planning. They comment that this integration is feasible because in their work on the planning of an urban forest the results obtained were introduced in the municipal plan of the locality.

The tools mentioned above have been applied in forest planning processes that are developed over considerable periods of time, sometimes lasting several years. However, there are situations in forest environments where decision making cannot wait, because the prevention of major disasters may depend on quick decisions, as in the case of large-scale forest fires. In these specific cases, a number of parameters such as topography, types of vegetable fuel in the area, meteorological conditions, transport networks, public services and facilities, etc., must be known, as indicated by Keramitsoglou et al. [53]. These authors propose the integration of Remote Sensing, GIS, and Relational Database Management System (RDMS) technology systems with interactive communication capabilities. The system combines all the information in real time so that it allows decisions to be made that adapt to the situation in which the fire is found [53].

On the other hand, Sheppard and Meitner [21] presented some premises that are related to how to achieve more effective forest management processes, through participation. Some of these issues involve evaluating the presence of stakeholder groups, as this contributes to impartiality and credibility, as well as allowing the participation of those less organized or experienced actors. In addition, they added that the information should be easy to understand, using graphics if necessary, for clarity. In the review carried out by Díaz-Balteiro and Romero [15] (p. 3227), the work of Sheppard and 
Meitner [21] is highlighted for proposing the use of " ... a decision-making model for sustainable forest management, involving local communities in Canada".

Following the participation guidelines proposed by Sheppard and Meitner [21], it is considered that one of the appropriate techniques for social actors to convey and debate their opinions is the focus group. This participatory technique consists of low-cost and semi-structured meetings involving a limited number of participants (Table 1), generally not exceeding 12 members, as recommended by Aigneren [54] or Mahlau, Briz, and de Felipe [55].

Table 1. Number of participants in focus groups.

\begin{tabular}{cc}
\hline Author & Number of Participants \\
\hline World Bank (1996) [56] & 4 to 12 \\
Aigneren (2002) [54] & 6 to 12 \\
Escobar and Bonilla-Jimenez (2009) [57] & 6 to 10 \\
Calvente and Rodríguez (2000) [58] & 7 to 10 \\
Mahlau et al. (2002) [55] & 6 to 12 \\
Rodríguez and Cerdá (2002) [59] & 4 to 10 \\
\hline
\end{tabular}

This technique has been applied to some forest research, such as Sheppard and Meitner [21], Prell et al. [9], Greene et al. [32], and Idrissou et al. [60]. For example, in the case of Prell et al. [9], with the use of a focus group together with interviews that were carried out, the relevance of the objectives proposed in the project was guaranteed.

MCDA applied in decision-making processes in the forest environment might include procedures and techniques that allow deliberations among the representatives of stakeholder groups. It will favour the success of the decisions taken. In addition, it can be observed that, along with the different assessment tools applied to decision making in the forest environment, there is an added value resulting from the different styles of participatory processes, showing the importance of inclusive processes in this type of analysis, which makes it especially important to dedicate a section to these processes.

\section{MCDA in Forest Environments from the Perspective of the Inclusion of Actors}

Participation can be evidenced, when it exists, in the collection of information, the assessment process, and, finally, in the discussion of results and decision making. In this sense, DSSs can be classified into four types (see Figure 2), taking into account the degree of participation of social actors. Starting with those more technocratic processes, there are MCDA without participation, where decision makers get assessment results based on the alternatives and criteria defined by the analyst. There are also those in which the data collection is based on the information provided by the stakeholders. However, there are cases in which the participation is more notable and not only intervenes in the input phase, but also, is part of the "Assessment Procedure". Finally, the most inclusive processes are those in which stakeholders are present in all phases, including in decision making, where they have the opportunity to participate in deliberations on the results of the assessment.

This description of the different degrees of participation of society in decision-making processes can have repercussions on interests and shows similarities to Arnstein's ladder [61]. For example, on the ladder's first steps is the most technocratic research, while the most participatory would be on the top ones. The degree of involvement of society could be influenced by the interests of a few who hold power. In this sense, Thomas [62] said that sometimes decision makers seek participation only to obtain ideas, reserving the privilege of decision making for themselves. In these situations, it is still a process with a certain technocratic character, since the role assumed by the citizens is that of mere informers. 


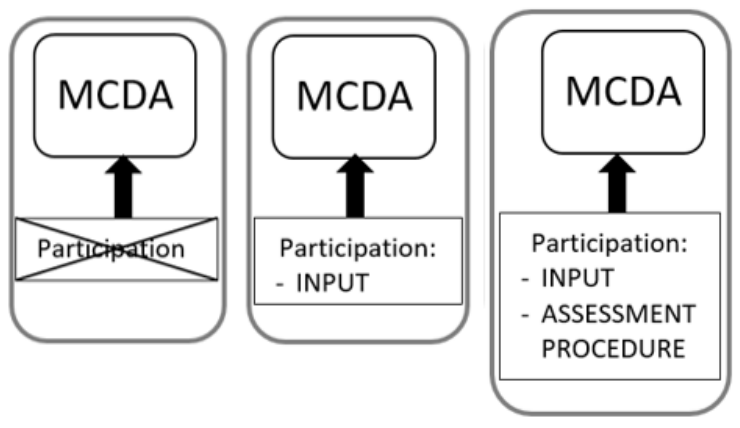

+ TECHNOCRATIC

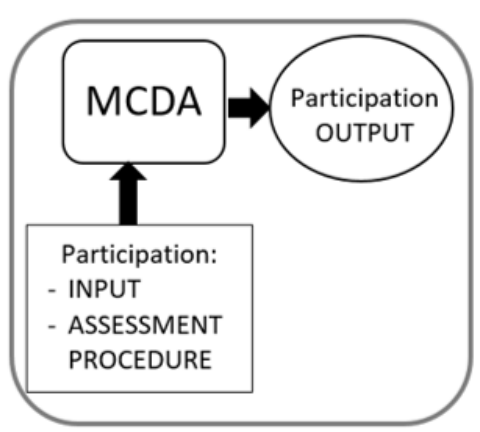

+ PARTICIPATORY

Figure 2. Classification of Multicriteria Decision Analysis (MCDA) (presented in Figure 3) according to degree of participation.

However, on other occasions, decision makers share responsibility for decision making with citizens. In the latter case, Thomas [62] states that participation should occur from the beginning of the research. We support this assertion because it facilitates participants' understanding and knowledge of the reasons that have led to the choice of certain options to be discussed at the time of decision making. If participation occurs only in this last phase, those involved may not share the proposed actions and question that this has motivated their choice, thus obliging decision makers to take a step back, to explain the whole process-this is time consuming and could lead to disagreement among stakeholders, with the end result being that the decision-making phase would not be effective. During this century, a relationship has not been detected between the temporal evolution and an increase in the participation of the social actors in decision-making processes (Figure 3). For example, in Hiltunen et al. [63], there is a greater degree of participation of society than in Hayati et al. [52]. The following sections will discuss some aspects about how, and at what stage of the processes, stakeholders have intervened in the investigations shown in Figure 3.

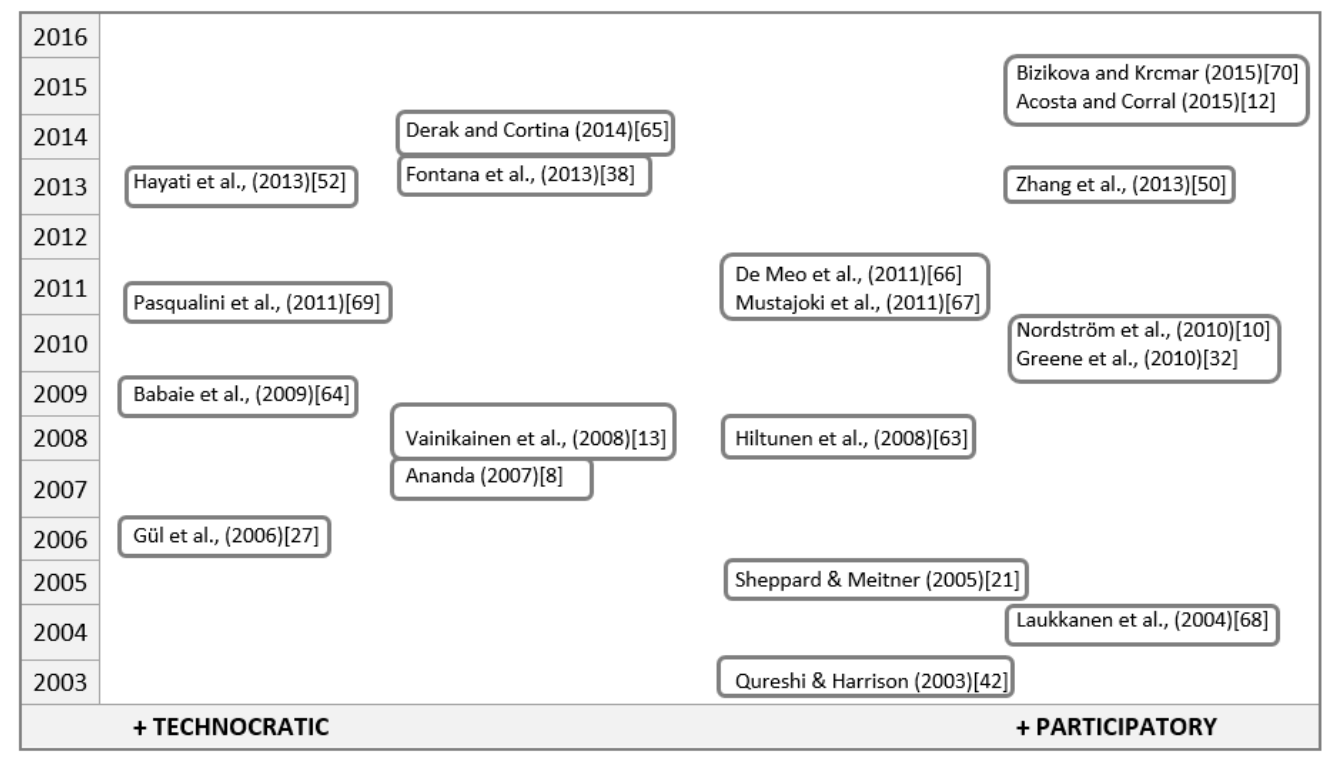

Figure 3. Classification of research according to degree of participation. Based on $[8,10,12,13,21,27,32,38,42,50,52,63-70]$. 
Studies such as Khadka et al. [71] have demonstrated that joint participation in the structuring of problems related to participatory forestry planning in the period 2002-2011 has, on a global level, increased and fostered commitment to agreements in some cases and improved knowledge sharing among social actors, experts, and authorities, while also contributing to the collaborative integration of scientific knowledge and non-experts. In this sense, several authors reaffirm the importance of involving social actors in environmental processes, such as Buchy and Hoverman [72], Funtowicz and Strand [73], Hernández-González, and Corral [74]; Kangas et al. [75], Kangas et al. [76], Mendoza and Prabhu [77], Nordström et al. [10], Saarikoski, et al. [78], Sheppard and Meitner [21], or Vainikainen et al. [13].

\subsection{Participation in the Proposal and Assessment of Alternatives}

In the processes developed for decision making on forest planning, the social actors can carry out the proposal of alternatives or even their assessment. For example, in research such as that carried out by Ananda [8], De Meo et al. [66], Acosta and Corral [12], Corral et al. [79], González and Quintana [80] or Nordström et al. [10] different degrees of involvement have been detected. In Ananda [8], the selection process of the alternatives was carried out with the participation of some forest service officials. This selection was based on the status quo and discussions with officials, and the data from various forest management reports were consulted. It could be said that in this case, participation on the choice of alternatives was limited. However, interviews were conducted so that the social actors made a peer-assessment of the alternatives and obtained a total of 2332 comparisons. Preferences in weights were quantified, allowing each group to know the opinion of the other participants, also contributing to the transparency of the process.

There is other research in which the degree of involvement of social actors in the choice of alternatives is greater. For example, in De Meo et al. [66], a participatory process was carried out through consultations to find out the preferences and perceptions of social actors in relation to forest landscape planning. The information gathered in this process, together with the data on forest inventories, led to the elaboration of a draft of planning alternatives. It should be noted that the interviews were structured in several sections, the first ones involved general data of interviewees and the rest dealt with questions related to forest management (a) grazing and the relationship between grazing and forest; (b) the link between farmers and the territory; and (c) the value attributed to landscape and the perception of changes in the landscape. This grouping allowed for an individualized analysis to be carried out, and the management guidelines were defined in a shared way by policy makers. De Meo et al. [66] emphasized that the questions were closed to facilitate the analysis and indicated that the data obtained from the interviews allowed a better understanding of the context of the area under study and revealed that this type of action is fundamental for the development of a forest landscape plan. However, we consider that although these types of questions may facilitate the analysis, they have a weak point, because through them, the participation of social actors is being limited, because actors cannot express all their knowledge or experiences on the subject under investigation. From our point of view, although the analyses are more laborious, in the structure of the interviews a space for open-ended questions as well as closed questions should be included, so as to allow a broader collection of the interviewees' perceptions.

This type of questionnaire, with closed and open questions, was used in the research developed by Acosta \& Corral [12]. This way of obtaining information allowed them to obtain better knowledge in relation to the different perceptions of social actors. Although the analysis was more complex, because it was necessary to organize all the data obtained to be able to process them, it was guaranteed that the assessed alternatives arose from the contributions of the social actors. In addition, the final phase of this research allowed representatives of stakeholder groups to discuss the results obtained.

Sometimes, when the research is related to the planning of the use of forest land, it is interesting to break with the monotony of surveys, in which a series of questions and answers follow, by providing maps that allow the interviewee to place their proposals geographically as to the different uses, thus 
achieving greater clarity of information. This type of questionnaire was used by Nordström et al. [10], where interviews were carried out in which maps were provided for social actors to identify areas of special interest and to express why they were important to them. Based on this information and based on existing forest data, three alternatives to strategic plans were presented. The social actors established their preferences through consultation forms and with the AHP, the classification of the alternatives was determined. Nordström et al. [10] indicated that in some situations where sufficient time is not available, it is necessary to present to the stakeholders a small number of actions, including expressing that implementing them, could be not only because of a lack of time, but also because of a lack of resources. They added that, since decision-making is based on proposed alternatives, they should be small and realistic, and should represent the interests of stakeholders.

\subsection{Choice of Criteria for Assessments in the Proposal and Assessment of Alternatives}

The social actors sometimes carry out the choice of criteria for assessments, whereas in other studies experts perform it. In some research published in 2013, the choice of parameters has been linked to experts (e.g., Fontana et al. [38] or Hayati et al. [52]). In the first case, criteria emerged from meetings that were held with 30 experts (agriculture, forestry, nature conservation, research, etc.) in forest land uses. While in the second, they surfaced via e-mail questionnaires sent to nine forestry engineering experts who were responsible for stating the most important criteria affecting the planning of the network of forest roads, from a technical, economic, and environmental point of view. However, in other research published previously, the voters for or against the criteria have been social actors (e.g., Hiltunen et al. [63] or Nordström et al. [10]). In the first case, eight criteria were selected that emerged from the discussions and were approved by consensus of the interested parties. They were related to issues of biodiversity, recreation and tourism, economy, and social impacts linked to the region. In the second case, it was the stakeholder representatives who proposed them through interviews. Nordström et al. [10] and Hiltunen et al. [63] stated that with stakeholder participation a better structuring of the problem had been achieved. Nordström et al. [10] further added that this action provides knowledge of the social perspective and greater transparency and credibility for interested parties. In the review by Díaz-Balteiro and Romero [15] (pp. 3228-3229), they emphasized that Hiltunen et al. [63] "proposed the use of GDM techniques in participatory strategic forest planning in state-owned forests in Finland. Five voting methods, including Borda's rule and voting approval were applied."

On the other hand, in relation to the weighting of criteria, a temporal progression of participation has not been found; for example, in Gül et al. [27] or Hayati et al. [52], it is the experts who carry out this work. In the case of research developed by Gül et al. [27], the weighting coefficients arose from surveys with local experts in green space management. In the case of Hayati et al. [52], information on the weightings of these parameters also arises through questionnaires. This way of developing the weighting of the criteria leaves aside the information that can be provided by social actors and that could benefit the results of the study. However, this is not the case in all research, since in some studies, such as those developed by Derak and Cortina [65], these data are obtained through interviews with social actors. In other studies, there is a further step towards participation and in addition to the weighting of the criteria by the people concerned, the results are discussed, and in those cases where they do not fit their preferences, there is an opportunity to adjust the weights, so that the results are close to the interviewee's opinions, as happened in Mustajoki et al. [67].

\subsection{Are Inclusive Processes Necessary in Input, Assessment Procedure, and Outcome Phases?}

It is considered that inclusive processes can be carried out in one or more of the phases (Input, Assessment Procedure, and Outcome) in which DSSs are developed. However, the existence of a procedure or guide that answers the following questions is not known:

(A) When should there be inclusive processes? 
(B) If there is participation in Input, should there also be participation in the following phases?

(C) If there is no participation in Input, can there be inclusive processes in the following phases?

In response to questions (B) and (C), some of the research examples above can be cited, in which some consider participation only in one phase, while in others, it is present in several of them. As an example of inclusion in one of the stages, we can cite the work of Ananda [8] or that of Hayati et al. [52]. In the first case, the stakeholders are present in the Input Phase, while in the second, they are in the Assessment Procedure. In Hiltunen et al. [63], Derak and Cortina [65], and De Meo et al. [66], greater participation has been observed. For example, in the first two, stakeholders' opinions were taken into account during the Input and Assessment Procedures, while in the latter, they were present in Input and Outcome, allowing them to define, together with decision makers, the guidelines for management. There is other research, of a more participative nature, that develops the three phases with the presence of the people involved, as happened in Acosta and Corral [12].

With regard to answering question (A), participation is considered to enrich and favour research. In addition, those affected should be present to achieve success in the decision making. However, we believe that participation should not be generalized by creating an application manual, since each study has its peculiarities that must be analysed to be able to trace an initial planning of each of the stages of the process, allowing them to be modified during its development. As stated by Guimarães and Corral [22] (p. 2): "One of the key features of a DSS would be an adaptive system that could correspond to participants' needs, i.e., supporting a variety of decision-making processes, yet independent of any one in particular."

A first contact with representatives of the different groups is advised in order to obtain more in-depth information related to the case study. However, sometimes the informants do not have sufficient knowledge to be able to give a reliable opinion, so it is recommended that the individuals responsible for collecting information should not be trainees, but should have adequate experience that allows them to detect if indeed the data are appropriate to be included in the process. Also, in the Outcome Phase, the presence of the different groups is also suggested, so that they can dialogue and discuss the results obtained. By contrast, the presentation of results in research in which there has been no initial participation can cause delays in the process, since participants may not share the different options that have been assessed and propose new alternatives, which may be accepted or not by others, leading in the latter case to the failure of decision making, as discussed previously.

\section{Conclusions}

This review of DSS reveals the importance of the development of processes that contemplate procedures that favour the success of decision making. Of the three types of MCDA defined, in relation to participation, the one that best fits the purpose is the one that not only allows social actors to contribute information and to express their preferences, but also enables them to deliberate the results obtained, as happened in Mustajoki et al. [67] or Acosta and Corral [12]. This type of debate contributes to the emergence of new alternatives, which in some cases could be more viable than those raised at the beginning of the processes. In addition, the presence of social actors in these processes allows greater knowledge of the state of the issue to be addressed, while also achieving mutual learning between participants and the decision makers. This will also ensure that the decisions taken are better received by the population, as discussed by Pereira and Quintana [81] and Van der Sluijs et al. [82].

Although participation sometimes occurs in the final stages of the processes, we advocate early participation, as some authors support, such as Nordström et al. [10]. Thus, a key question that arises is 'what limits, on some occasions, a more active collaboration of society in the decision-making processes?' We believe that this can be due to several reasons, among them the lack of information in communities in relation to the environmental issues that are linked to the forest environments, and for this reason the tendency of managers to disregard the opinions of social actors. This lack could be solved through providing information and training among society members, so that they are aware of the perceptions and values that lead to the sustainability of forest environments. Another possible 
cause could be the interests of certain circles at the top, which may be adversely affected by the views of social actors. However, we cannot generalize-it would be necessary to study in each case the reason for this lack of participation, since each geographical area is characterized by a series of factors (environmental, social, economic, and legal) that cannot be extrapolated to other places.

Regarding the application of procedures or tools, the use of MCDA stands out because it allows the treatment of the environmental, social, and economic dimensions that are present in forest environments. Likewise, although we recognize that it is more laborious, the use of questionnaires that include open and closed questions is suggested during data collection in order to allow the stakeholders to be able to openly express their needs and points of view.

In addition, it is advisable to use maps or schemes that help stakeholders to not only better understand the process, but to also serve as a basis for researchers to present the results of the assessment, thereby facilitating discussion among participants. In short, MCDA should contemplate procedures or techniques through which the participation of social actors in all phases of the process is allowed.

Finally, we consider that it is not possible to generalize, so each study must be planned so that during its development, modifications are allowed. In addition, we advocate strongly for the presence of stakeholders in different stages (Input, Assessment Procedure, and Outcome) in the terms discussed above.

Author Contributions: Montserrat Acosta carried out the analysis. Corral Quintana provided expertise in methodology and structure of the assessment. The article was improved by the contributions of all of the co-authors at various stages of the analysis and writing process.

Conflicts of Interest: The authors declare no conflict of interest.

\section{References}

1. Sprague, R.H., Jr. A framework for the development of decision support systems. MIS Q. 1980, 4, 1-26. [CrossRef]

2. Kangas, A.; Kurttila, M.; Kangas, J.; Hujala, T.; Eyvindson, K. Decision Support for Forest Management; Springer: New York, NY, USA, 2015.

3. Matthies, M.; Giupponi, C.; Ostendorf, B. Environmental decision support systems: Current issues, methods and tools. Environ. Model. Softw. 2007, 22, 123-127. [CrossRef]

4. European Comission. Sustainable Forestry and the European Union Initiatives of the European Commission; European Comission: Brussel, Belgium, 2003.

5. Mysiak, J.; Giupponi, C.; Rosato, P. Towards the development of a decision support system for water resource management. Environ. Model. Softw. 2005, 20, 203-214. [CrossRef]

6. Kangas, A.; Kangas, J.; Pykäläinen, J. Outranking methods as tools in strategic natural resources planning. Silva Fenn. 2001, 35, 215-227. [CrossRef]

7. Eom, S.B. Decision support systems research: Current state and trends. Ind. Manag. Data Syst. 1999, 99, 213-221. [CrossRef]

8. Ananda, J. Implementing participatory decision making in forest planning. Environ. Manag. 2007, 39, 534-544. [CrossRef] [PubMed]

9. Prell, C.; Hubacek, K.; Reed, M. Stakeholder analysis and social network analysis in natural resource management. Soc. Nat. Resour. 2009, 22, 501-518. [CrossRef]

10. Nordström, E.; Eriksson, L.O.; Öhman, K. Integrating multiple criteria decision analysis in participatory forest planning: Experience from a case study in northern Sweden. For. Policy Econ. 2010, 12, 562-574. [CrossRef]

11. Rosenberger, R.S.; Needham, M.D.; Morzillo, A.T.; Moehrke, C. Attitudes, willingness to pay, and stated values for recreation use fees at an urban proximate forest. J. For. Econ. 2012, 18, 271-281. [CrossRef]

12. Acosta, M.; Corral, S. Participatory Multi-Criteria Assessment of Forest Planning Policies in Conflicting Situations: The Case of Tenerife. Forests 2015, 6, 3946-3969. [CrossRef]

13. Vainikainen, N.; Kangas, A.; Kangas, J. Empirical study on voting power in participatory forest planning. J. Environ. Manag. 2008, 88, 173-180. [CrossRef] [PubMed] 
14. Kangas, J.; Kangas, A. Multiple criteria decision support in forest management-The approach, methods applied, and experiences gained. For. Ecol. Manag. 2005, 207, 133-143. [CrossRef]

15. Díaz-Balteiro, L.; Romero, C. Making forestry decisions with multiple criteria: A review and an assessment. For. Ecol. Manag. 2008, 255, 3222-3241. [CrossRef]

16. Kangas, A.; Laukkanen, S.; Kangas, J. Social choice theory and its applications in sustainable forest management-A review. For. Policy Econ. 2006, 9, 77-92. [CrossRef]

17. Ananda, J.; Herath, G. A critical review of multi-criteria decision making methods with special reference to forest management and planning. Ecol. Econ. 2009, 68, 2535-2548. [CrossRef]

18. De Steiguer, J.E.; Liberti, L.; Schuler, A.; Hansen, B. Multi-Criteria Decision Models for Forestry and Natural Resources Management: An Annotated Bibliography; United States Department of Agriculture, Forest Service, Northeastern Forest Experiment Station: Upper Darby, PA, USA, 2003.

19. Mendoza, G.A.; Martins, H. Multi-criteria decision analysis in natural resource management: A critical review of methods and new modelling paradigms. For. Ecol. Manag. 2006, 230, 1-22. [CrossRef]

20. Romero, C. Modelos de planificación forestal: Una aproximación desde el análisis multicriterio. Rev. Estud. Agro-Soc. 1989, 147, 71-92.

21. Sheppard, S.R.J.; Meitner, M. Using multi-criteria analysis and visualisation for sustainable forest management planning with stakeholder groups. For. Ecol. Manag. 2005, 207, 171-187. [CrossRef]

22. Pereira, A.G.; Quintana, S.C. From technocratic to participatory decision support systems: Responding to the new governance initiatives. J. Geogr. Inf. Decis. Anal. 2002, 6, 95-107.

23. Kilgour, D.M.; Eden, C. Handbook of Group Decision and Negotiation; Springer Science \& Business Media: New York, NY, USA, 2010; Volume 4.

24. Gorry, G.A.; Scott Morton, M.S. A Framework for Management Information Systems; Massachusetts Institute of Technology: Cambridge, MA, USA, 1971.

25. Scott Morton, M.S. State of the Art of Research in Management Support Systems; Massachusetts Institute of Technology: Cambridge, MA, USA, 1983.

26. Paneque Salgado, P.; Corral Quintana, S.; Guimaraes Pereira, A.; del Moral Ituarte, L.; Pedregal Mateos, B. Participative multi-criteria analysis for the evaluation of water governance alternatives. A case in the Costa del Sol (Málaga). Ecol. Econ. 2009, 68, 990-1005. [CrossRef]

27. Gül, A.; Gezer, A.; Kane, B. Multi-criteria analysis for locating new urban forests: An example from Isparta, Turkey. Urban For. Urban Green. 2006, 5, 57-71. [CrossRef]

28. Corral Quintana, S. Una Metodología Integrada de Exploración y Comprensión de los Procesos de Elaboración de Políticas Públicas; Universidad de La Laguna: Santa Cruz de Tenerife, Spain, 2004.

29. Corral-Quintana, S.; Legna-de la Nuez, D.; Verna, C.L.; Hernández, J.H.; de Lara, D.R. How to improve strategic decision-making in complex systems when only qualitative information is available. Land Use Policy 2016, 50, 83-101. [CrossRef]

30. Joint Research Centre of the European Commission. NAIADE Manual and Tutorial-Versión 1.0. ENG; Joint Research Centre of the European Commission: Brussel, Belgium, 1996.

31. Clarke, K.C. Advances in geographic information systems. Comput. Environ. Urban Syst. 1986, 10, $175-184$. [CrossRef]

32. Greene, R.; Luther, J.E.; Devillers, R.; Eddy, B. An approach to GIS-based multiple criteria decision analysis that integrates exploration and evaluation phases: Case study in a forest-dominated landscape. For. Ecol. Manag. 2010, 260, 2102-2114. [CrossRef]

33. Fürst, C.; Frank, S.; Witt, A.; Koschke, L.; Makeschin, F. Assessment of the effects of forest land use strategies on the provision of ecosystem services at regional scale. J. Environ. Manag. 2013, 127, S96-S116. [CrossRef] [PubMed]

34. Ramani, T.; Zietsman, J.; Eisele, W.; Rosa, D.; Spillane, D.; Bochner, B. Developing Sustainable Transportation Performance Measures for TXDOT's Strategic Plan: Technical Report; Texas Department of Transportation: Austin, TX, USA, 2009.

35. O'Connor, M. The VALSE project-An introduction. Ecol. Econ. 2000, 34, 165-174. [CrossRef]

36. Keeney, R.L. Decision analysis: An overview. Oper. Res. 1982, 30, 803-838. [CrossRef] [PubMed]

37. Belton, V.; Stewart, T. Multiple Criteria Decision Analysis: An Integrated Approach; Springer Science \& Business Media: New York, NY, USA, 2002. 
38. Fontana, V.; Radtke, A.; Fedrigotti, V.B.; Tappeiner, U.; Tasser, E.; Zerbe, S.; Buchholz, T. Comparing land-use alternatives: Using the ecosystem services concept to define a multi-criteria decision analysis. Ecol. Econ. 2013, 93, 128-136. [CrossRef]

39. Munda, G. Multicriteria Evaluation in a Fuzzy Environment: Theory and Applications in Ecological Economics; Physica-Verlag: Heidelberg, Germany, 1995.

40. Weintraub, A.; Bare, B.B. New issues in forest land management from an operations research perspective. Interfaces 1996, 26, 9-25. [CrossRef]

41. Ananda, J.; Herath, G. The use of Analytic Hierarchy Process to incorporate stakeholder preferences into regional forest planning. For. Policy Econ. 2003, 5, 13-26. [CrossRef]

42. Qureshi, M.E.; Harrison, S.R. Application of the analytic hierarchy process to riparian revegetation policy options. Small-Scale For. 2003, 2, 441-458.

43. Lexer, M.; Vacik, H.; Palmetzhofer, D.; Oitzinger, G. A decision support tool to improve forestry extension services for small private landowners in southern Austria. Comput. Electron. Agric. 2005, 49, 81-102. [CrossRef]

44. Diaz-Balteiro, L.; Romero, C. Sustainability of forest management plans: A discrete goal programming approach. J. Environ. Manag. 2004, 71, 351-359. [CrossRef] [PubMed]

45. Kurttila, M.; Pesonen, M.; Kangas, J.; Kajanus, M. Utilizing the analytic hierarchy process (AHP) in SWOT analysis-A hybrid method and its application to a forest-certification case. For. Policy Econ. 2000, 1, 41-52. [CrossRef]

46. Hotvedt, J.E. Application of linear goal programming to forest harvest scheduling. South. J. Agric. Econ. 1983, 15, 103-108. [CrossRef]

47. Fischer, G.; Makowski, M.; Antoine, J. Multiple Criteria Land Use Analysis; IIASA: Laxenburg, Austria, 1996.

48. Steuer, R.E.; Schuler, A.T. An interactive multiple-objective linear programming approach to a problem in forest management. Oper. Res. 1978, 26, 254-269. [CrossRef]

49. Sheppard, S.R. Participatory decision support for sustainable forest management: A framework for planning with local communities at the landscape level in Canada. Can. J. For. Res. 2005, 35, 1515-1526. [CrossRef]

50. Zhang, Z.; Sherman, R.; Yang, Z.; Wu, R.; Wang, W.; Yin, M.; Yang, G.; Ou, X. Integrating a participatory process with a GIS-based multi-criteria decision analysis for protected area zoning in China. J. Nat. Conserv. 2013, 21, 225-240. [CrossRef]

51. Hytönen, L.A.; Leskinen, P.; Store, R. A spatial approach to participatory planning in forestry decision making. Scand. J. For. Res. 2002, 17, 62-71. [CrossRef]

52. Hayati, E.; Majnounian, B.; Abdi, E.; Sessions, J.; Makhdoum, M. An expert-based approach to forest road network planning by combining Delphi and spatial multi-criteria evaluation. Environ. Monit. Assess. 2013, 185, 1767-1776. [CrossRef] [PubMed]

53. Keramitsoglou, I.; Kiranoudis, C.T.; Sarimvels, H.; Sifakis, N. A multidisciplinary decision support system for forest fire crisis management. Environ. Manag. 2004, 33, 212-225. [CrossRef] [PubMed]

54. Aigneren, M. La técnica de recolección de información mediante los grupos focales. Rev. Electrón. Sociol. Escen. 2002, 6, 1-32.

55. Mahlau, M.; Briz, J.; de Felipe, I. Actitud y comportamiento de consumidores alemanes respecto al aceite de oliva: Un análisis de sesiones de grupo objetivo (focus group). Rev. Esp. Estud. Agro-Soc. Pesq. 2002, 194, 147-168.

56. The World Bank. The World Bank Participation Sourcebook; The World Bank: Washington, DC, USA, 1996.

57. Escobar, J.; Bonilla-Jimenez, F.I. Grupos focales: Una guía conceptual y metodológica. Cuad. Hispanoam. Psicol. 2009, 9, 51-67.

58. Calvente, M.G.; Rodríguez, I.M. El grupo focal como técnica de investigación cualitativa en salud: Diseño y puesta en práctica. Aten. Prim. 2000, 25, 181-186. [CrossRef]

59. Rodríguez, M.P.; Cerdá, J.M. Paso a paso en el diseño de un estudio mediante grupos focales. Aten. Prim. 2002, 29, 366-373. [CrossRef]

60. Idrissou, L.; van Paassen, A.; Aarts, N.; Leeuwis, C. From cohesion to conflict in participatory forest management: The case of Ouémé Supérieur and N’Dali (OSN) forests in Benin. For. Policy Econ. 2011, 13, 525-534. [CrossRef]

61. Arnstein, S.R. A ladder of citizen participation. J. Am. Inst. Plan. 1969, 35, 216-224. [CrossRef] 
62. Thomas, J.C. Citizen, customer, partner: Rethinking the place of the public in public management. Public Adm. Rev. 2013, 73, 786-796. [CrossRef]

63. Hiltunen, V.; Kangas, J.; Pykäläinen, J. Voting methods in strategic forest planning-Experiences from Metsähallitus. For. Policy Econ. 2008, 10, 117-127. [CrossRef]

64. Babaie-Kafaky, S.; Mataji, A.; Sani, N.A. Ecological capability assessment for multiple-use in forest areas using GIS-based multiple criteria decision making approach. Am. J. Environ. Sci. 2009, 5, 714. [CrossRef]

65. Derak, M.; Cortina, J. Multi-criteria participative evaluation of Pinus halepensis plantations in a semiarid area of southeast Spain. Ecol. Ind. 2014, 43, 56-68. [CrossRef]

66. De Meo, I.; Cantiani, M.G.; Ferretti, F.; Paletto, A. Stakeholders' perception as support for forest landscape planning. Int. J. Ecol. 2011, 2011, 685708. [CrossRef]

67. Mustajoki, J.; Saarikoski, H.; Marttunen, M.; Ahtikoski, A.; Hallikainen, V.; Helle, T.; Hyppönen, M.; Jokinen, M.; Naskali, A.; Tuulentie, S. Use of decision analysis interviews to support the sustainable use of the forests in Finnish Upper Lapland. J. Environ. Manag. 2011, 92, 1550-1563. [CrossRef] [PubMed]

68. Laukkanen, S.; Kangas, A.; Kangas, J. Applying voting theory in natural resource management: A case of multiple-criteria group decision support. J. Environ. Manag. 2002, 64, 127-137. [CrossRef]

69. Pasqualini, V.; Oberti, P.; Vigetta, S.; Riffard, O.; Panaïotis, C.; Cannac, M.; Ferrat, L. A GIS-based multicriteria evaluation for aiding risk management Pinus pinaster Ait. forests: A case study in Corsican Island, Western Mediterranean region. Environ. Manag. 2011, 48, 38. [CrossRef] [PubMed]

70. Bizikova, L.; Krcmar, E. Integrated scenario planning and multi-criteria decision analysis framework with application to forest planning. Open J. For. 2015, 5, 139. [CrossRef]

71. Khadka, C.; Hujala, T.; Wolfslehner, B.; Vacik, H. Problem structuring in participatory forest planning. For. Policy Econ. 2013, 26, 1-11. [CrossRef]

72. Buchy, M.; Hoverman, S. Understanding public participation in forest planning: A review. For. Policy Econ. 2000, 1, 15-25. [CrossRef]

73. Funtowicz, S.; Strand, R. De la demostración experta al diálogo participativo. Rev. Iberoam. Cienc. Tecnol. Soc. 2007, 3, 97-113.

74. Hernández-González, Y.; Corral, S. An extended peer communities' knowledge sharing approach for environmental governance. Land Use Policy 2017, 63, 140-148. [CrossRef]

75. Kangas, A.; Saarinen, N.; Saarikoski, H.; Leskinen, L.A.; Hujala, T.; Tikkanen, J. Stakeholder perspectives about proper participation for Regional Forest Programmes in Finland. For. Policy Econ. 2010, 12, $213-222$. [CrossRef]

76. Kangas, A.; Heikkilä, J.; Malmivaara-Lämsä, M.; Löfström, I. Case Puijo-Evaluation of a participatory urban forest planning process. For. Policy Econ. 2014, 45, 13-23. [CrossRef]

77. Mendoza, G.A.; Prabhu, R. Combining participatory modeling and multi-criteria analysis for community-based forest management. For. Ecol. Manag. 2005, 207, 145-156. [CrossRef]

78. Saarikoski, H.; Tikkanen, J.; Leskinen, L.A. Public participation in practice-Assessing public participation in the preparation of regional forest programs in Northern Finland. For. Policy Econ. 2010, 12, 349-356. [CrossRef]

79. Corral, S.; Legna-de la Nuez, D.; de Lara, D.R. Integrated assessment of biofuel production in arid lands: Jatropha cultivation on the island of Fuerteventura. Renew. Sustain. Energy Rev. 2015, 52, 41-53. [CrossRef]

80. Hernández-González, Y.; Corral Quintana, S. An integrated assessment of alternative land-based passenger transport policies: A case study in Tenerife. Transp. Res. Part A Policy Pract. 2016, 89, 201-214. [CrossRef]

81. Pereira, Â.G.; Quintana, S.C. 3 pillars and 1 beam: Quality of river basin governance processes. Ecol. Econ. 2009, 68, 940-954.

82. Van Der Sluijs, J.; Douguet, J.; O'Connor, M.; Pereira, Â.G.; Quintana, S.C.; Maxim, L.; Ravetz, J.R. Qualité de la connaissance dans un processus délibératif. Nat. Sci. Soc. 2008, 16, 265-273. [CrossRef]

(C) 2017 by the authors. Licensee MDPI, Basel, Switzerland. This article is an open access article distributed under the terms and conditions of the Creative Commons Attribution (CC BY) license (http:/ / creativecommons.org/licenses/by/4.0/). 